\title{
Speech Acts in Billboard Messages of the Redeemed Christian Church of God, Redemption Camp, Nigeria: A Pragmatic Study
}

\author{
Idowu Odebode ${ }^{1}, \mathrm{PhD} \&$ Oluwabukola Dabi ${ }^{1}$ \\ ${ }^{1}$ Department of English, Redeemer's University, Ede, Osun State, Nigeria \\ Correspondence: Idowu Odebode, PhD, Department of English, Redeemer's University, Ede, Osun State, Nigeria. \\ E-mail: odebodei@run.edu.ng; iodebode@yahoo.com) \\ Received: March 21, 2015 \\ Accepted: April 27, 2015 \\ Online Published: May 10, 2015 \\ doi:10.5430/elr.v4n2p17 \\ URL: http://dx.doi.org/10.5430/elr.v4n2p17
}

\begin{abstract}
Several studies have existed on various aspects of advertisement billboards and stickers, using different scholastic approaches. But none, to the best of our knowledge, has delved into the pragmatic analysis of religious billboards in The Redeemed Christian Church of God, Redemption Camp, Nigeria. This study is an attempt at filling this gap. The study is based on Austin's (1962) Speech Act theory. Seventeen billboards which were purposively selected served as our data. The data were analysed based on the theory in order to validate the following research questions: What are the pragmatic elements inherent in the billboards? What types of speech acts are preponderant in the billboards? Can we establish that the billboards communicate meaningful messages to the worshippers? The study indicated a preponderance of the illocutionary acts of informing and advising and demonstrated that the billboards are inundated with various meaning-making strategies which enhance their multifarious interpretations.
\end{abstract}

Keywords: Redeem, Adeboye, Speech Acts, Akindayomi

\section{Introduction}

Language is a vital instrument which aids the communicative ability of the members of any given society or geographical territory. Consequently, the choice of language in a particular environment serves as a viable instrument in knitting them together. The language chosen enhances the culture, traditions, values, norms and technological development of that given speech community. It is important to note that the choice and meaning of that language is valued when it is studied in the context in which it has been used. This is necessary because "meanings are constantly being reshaped (or refurbished), not by any legislation but through inevitable interaction in the 'semiotic contexts' of minute aspect of the general society of daily life." (Oyeleye 2005, p.5).

It should also be noted that since language is a human phenomenon and human beings inhabit societies, the study of language use in any given society cannot be jettisoned. This is why pragmatics captures how language is used in a particular social context and how meaning can be extracted from its use. This study therefore is based on a pragmatic analysis of selected billboards in The Redeemed Christian Church of God, Redemption Camp, Nigeria.

\subsection{A Brief Historical Background of The Redeemed Christian Church of God}

The Redeemed Christian Church of God started in 1952 by Pa Josiah Akindayomi. He was born in July 1909 in Ondo State, Nigeria. He was called to be a servant of God in 1931. But the call was ignored for nine years. He finally surrendered in 1940, when he got his confirmation through Bible passages of Jeremiah 1:4-10, Isaiah 41:10-13 and Romans 8:29-31.

He attended the Cherubim and Seraphim church before he commenced a house fellowship at Willoughby street, Ebute-Metta, Lagos, Nigeria with his wife. He was a man of prayers and before long many flocked to him for prayers. The fellowship was called "Ijo Ogo Oluwa" (The Glory of God Fellowship). Initially there were nine members but before long, the fellowship grew rapidly as unimaginable events started taking place. The name of the church The Redeemed Christian Church of God was gotten in a vision by the founder. The church started formally in 1952 at 1-5 Redemption way, Ebute-Metta (formerly Cemetery street), Lagos which is the present National headquarters of the church. The church has experienced unprecedented growth from the period it started in 1952 to date.

After the death of the founder also known as the General Superintendent, Pastor Enoch Adeboye became the leader of the church, having been chosen by Pa Akindayomi before his death. Pastor Adeboye joined The Redeemed 
Christian Church of God in 1973 and rapidly became the personal interpreter cum translator of Pa Akindayomi. The church is driven by its vision to take as many people as possible to heaven through the preaching of the word of God and holy living. As a result of these, the church has established more than 5000 parishes nationwide and her presence is felt in more than 20 nations in the world (Bankola, 2001). Later, the church acquired some portions of land in Kilometer 46, along Lagos/Ibadan Expressway in Nigeria. The place later grew to become the Redemption City which is housing the largest Christian auditorium in Africa (http://proshareng.com/news/3349). Analysis of the messages of the different billboards hung in the church auditorium (which is a kilometer long) is our concern in the present study.

\subsection{Theoretical Framework}

Speech acts is a technical term in linguistics and philosophy of language. It captures an action performed by someone through his words. The British philosopher J. L. Austin (1962) who contributed the term (speech acts) to pragmatics claimed that, by speaking, a person performs an act, or does something (such as state, predict, or warn) and that meaning is found in what an expression does. Simply put, the central aspect of the Speech Act theory is that an utterance is part of an action within the framework of social institution and conventions. Austin proposed three levels of speech acts: locutionary act, illocutionary act and perlocutionary act.

A locutionary act is the actual utterance and its ostensible meaning, comprising phonic, phatic and rhetic acts actually correspond to the verbal, syntactic and semantic aspects of any meaningful utterance. A phonic act produces an utterance-inscription. It is concerned with physical act of producing a certain sequence of vocal sounds (in the case of spoken language), or a set of written symbols (in the case of written language). A phatic act is an act of composing a particular linguistic expression in a particular language. It is the act of constructing a well formed string of sounds/symbols (a word, phrase, or sentence in a particular language). Rhetic act is an act of contextualising the utterance-inscription (Austin 1962). It is responsible for tasks such as assigning reference, resolving deixis, and disambiguating the utterance-inscription lexically and grammatically.

By the idea of illocutionary act, Austin believes that saying is doing. Therefore, "by saying something, we do something else." For instance when someone orders someone else to come by saying "Come!", or when a minister joins two people in marriage saying, "I now pronounce you husband and wife." An interesting type of illocutionary act is that performed in the utterance of what Austin calls performatives. Typical instances of these are "I demand an apology", "I ensure you there will be a change." In these rather explicit cases of performative sentences, the action that the sentences describe (demanding, ensuring) are performed by the utterance of the sentences themselves.

Furthermore, Austin explains that perlocutionary acts entail the consequences or effects of utterances on the audience in a linguistic encounter; such consequences or effects being special to the circumstances of utterance. Its actual effect, such as persuading, convincing, scaring, enlightening, inspiring, or otherwise getting someone to do or realize something, whether intended or not (Austin, 1962). For instance, the locution 'See a snake behind you' has an illocutionary act of informing or warning. The perlocutionary act will be manifested in the addressee who either runs or screams.

\section{Literature Review}

Several attempts have been made by scholars towards unraveling the concept of advertising with billboard using different linguistic stylistic approaches. This section is devoted to a review of such relevant scholarly works.

Adegbite (1997) studies "Pragmatics: Some Basic Principles and Procedures". He asserts that the importance of pragmatics to language is that it enables scholars and students to understand the principles and procedures guiding the interpretation of socio-cultural and contextual meanings of utterances. The researcher recognises three inter-related levels of semiotics, viz syntactic, semantic and pragmatic levels. Syntax relates signs to one another, semantics relates signs to their real objects and pragmatics relates signs to users of a language.

It should be noted that the present study is related to Adegbite's work because the two studies are pragmatically based.

Adeyanju (2008) critically examines "Stylo-Semantic analysis of Pastor Adeboye's New Year Compliments". He uses the contents of the greeting cards sent to members of the Redeemed Christian Church of God by Pastor Enoch Adejare Adeboye to commemorate the beginning of 2003 as his corpus. The study is a painstaking one as it reveals a cohesive use of linguistic and literary resources in handling two main themes: first, the passage of time and brevity of life on earth; second, prayers for revival and abundant life. 
The study is based on Halliday's Systemic Functional Grammar and reveals that the message(s) deviates from the normal pattern of complimentary expressions in greeting cards. It rather focuses on the vanity of the worldly riches and human accountability on the last day.

The study adopts certain graphological (italicization, capitalization, punctuation, indentation), lexico-semantic and rhetorical features to aid and enhance better understanding of the text. Stylistically, Adeyanju is able to bring out the two means of communication the Overseer uses to interact with his followers and with God. These are the vertical and horizontal means. The vertical communication captures his supplication to God, while the horizontal communication has to do with his message to the children of God.

This study is similar to ours because it centers on a message by the General Overseer of the church (The Redeemed Christian Church of God) whose billboards we are examining at present. However, the study is different from the present in theoretical frameworks. While Adeyanju uses aspects of the Systemic Functional Grammar as his framework, we are using Austin's (1962) Speech Acts as our theoretical orientation.

Ajibola (2008) analyses billboards' advertisements from a linguistic-stylistic perspective. He discovers that there are some features peculiar to the advertisements of particular telecommunication companies like MTN, Zain and Globacom. He notes the shortness, simplicity, acuity, clearness, and vividness of the billboard texts. According to him, billboard advertisements do not only make their readers' eyes glued to them, they sometimes play on their psych.

With the above in view, the researcher has been able to identify and analyse the linguistic elements in the study. This makes us understand the rationale behind the choice of lexemes in the texts of the billboards. He further accentuates on foregrounding items like mood system which, according to Osisanwo (2003, p.66), is basically concerned with the situation of the subject in the clause structure i.e. whether the speaker has chosen a subject or not.

The study also helps us to understand that billboards texts do not occur by accident but they are designed through careful selections and artistic brilliance on the part of the composers. The work is similar to ours because we hope to analyse billboards in this study. But it differs because while the researcher analyses telecommunication billboards, we are focusing on a Pentecostal church's billboards.

Anko (2010) researches on "Between Explicatures and Implicatures: Deconstructing the Pragmatic Interface in Advertisements". He affirms that advertisement as a form of communication actually draws a lot of attention as people naturally want to read or listen to what an advert is all about. He identifies two types of advertising. They are consumer advertising and public-servicing advertising. Consumer advertising is one of the means used by manufacturing and service industries to ensure the distribution of commodities to people in society at large and is designed to create demand for such goods services.

Public-servicing advertising is a means used by government or other authorities to convey particular/specific messages designed to achieve well-defined positive changes in the behaviour patterns of the different sectors of life in society. The link between the two therefore, is the ability to persuade the public because the basic goal of advertising is to persuade and convert the target audience.

Lasisi (2008) does a "linguistic study of English usage in selected print media advertisements in Nigeria". He discovered some recurring features which are peculiar to the language of print advertisements shown in the Tell magazine which is his selection. At the level of graphology, the language of print media advertisement makes use of capitalisation and punctuation distinctively to indicate clarity and meaning. It is also observed that the print media uses these graphological features as a useful device of economy of words because of little space for advertisements.

Lasisi also submits that the use of other linguistic features like grammar, lexis, and extra-linguistics elements have greatly contributed to the importance of advertisement, by enhancing its meaning and adding to its effect in our society in so many ways. Though the work is credible and linguistic-stylistic in nature, it is different from the present study which is pragmatically based. More specifically, the study uses general advertisement in print media. This is another divergence from the present study which uses Christian billboards as its data.

Lawal (1997) examines 'Pragmatics in stylistics: A speech-act analysis of Soyinka's Telephone conversation'. The researcher delves into the origin of pragmatics as an arm of linguistics and the place of speech act theory in a pragmatic model of stylistic analysis. The result of analysis of the poem indicates that the poem is a complex meta-conversation with a predominantly verdictive illocutionary force involving indirect mutual evaluation and prejudice. The work and the present study are related in the aspect of theoretical framework. But while Lawals' is stylistically grounded, ours is pragmatically enacted. 
Ogunsiji (2002) deploys the speech act theory in his analysis of Wole Soyinka's Etike Revo Wetin? According to him, Etike Revo Wetin? is a song that constitutes a form of poetry which has an instantaneous appeal. Basically, it satirizes the "Ethical Revolution" of the government of the Second Republic in Nigeria. The song constitutes a speech act with the illocutionary force of condemning, protesting against or satirizing the act of bad governance in Nigeria. The society of the poet can be felt through the poem to be corrupt; there is lack of true patriotism on the part of those in government; egocentric tendency is at its highest. The theoretical framework used for the study is similar to ours. But the works differ in the aspect of the data analysed.

\section{Data Analysis}

This section deals with an exploration of the speech act theory on our data. Each datum is benchmarked with the speech act principle as proposed by Austin (1962). This is with a view to underscore its presupposition, inference and implicature in order to account for its total meaning. Presupposition, in pragmatics, is an assumption about the world whose truth is taken for granted in discourse. For instance, You are here again presupposes You have been here before. Yule (1985, p.132) posits that "What a speaker assumes is true or is known by the hearer can be described as a presupposition". Inference is the activity performed by a reader or interpreter in drawing conclusions that are not explicit in what is said. It is the act or process of deriving a conclusion based solely on what one already knows. This is why Levinson (2005, p.13-14) views it as meaning components which are context dependent. Implicature is a technical term which is introduced into pragmatics by Grice (1975) for accounting for the implications of an utterance that goes beyond what is strictly implied by the content of the utterance; or a violation of any of the conversational maxims (see Grice, 1975).

\section{Discussion}

\section{Text 1: "The fear of the lord is the beginning of wisdom" (Proverbs 1:7)}

This statement has the following pragmatic interpretation: The illocutionary act of the statement is informing. The addresser (i.e. Solomon who presumably writes the book of Proverbs) is informing his reader/audience (addressee) on the benefit of having godly fear. The presupposition is that there is a lord whose fear can bequeath wisdom. The phrase "is the beginning" also presupposes the possibility of increasing or growing in wisdom. The inference is that since God is the author of wisdom, whoever disregards him is not wise. The implicature is that wisdom comes from the lord.

\section{Text 2: "The way of the lord is strength to the upright" (Proverbs 10:29)}

Text 2 has the following pragmatic import: The illocutionary act of the statement is informing. The presupposition is that there is a lord who has a particular way which is capable of strengthening the upright. The inference is that the addressees can only be strengthened by the way if they remain upright, otherwise, they become weak. The implicature is that he (God) strengthens.

\section{Text 3: "The fear of the lord prolongeth days" (Proverbs 10:27)}

Text 3 in the table has the following pragmatic deduction: The illocutionary act of the statement is advising. This is based on the presupposition that there is a lord who deserves to be feared. The inference is that anyone can die anytime. So, if the addressees want to live long, they are advised to fear the lord; hence the implicature of the statement i.e. to fear the lord.

\section{Text 4: "The ways of man are before the eyes of the lord" (Proverbs 5:21)}

The statement above has the following pragmatic exploration: The illocutionary act is informing. The presupposition is that the ways of man are before the eyes of the lord. The inference is that the lord watches us. The implicature is that we should watch our ways or steps.

\section{Text 5: "But if thou forsake him, he will cast thee off forever" (1 Chronicles 28:9)}

The quotation above has the following pragmatic analysis: The illocutionary act is informing. This is contingent on the assumption that God has the power to cast off forever. The inference is that the addressee's salvation is conditioned upon continuing with God, because forsaking him will lead to being cast away forever. The implicature is that we should not forsake him.

\section{Text 6: "I sought the lord and he heard me" (Psalm 34:4)}

Text 6 has the following pragmatic interpretation: The illocutionary act of the statement is informing. The presupposition is that there is a lord and he has a listening ear. The inference is that he can be pacified by a genuine seeker. The implicature is that the reader should always seek the lord. 
Text 7: "He blesseth the habitation of the just" (Proverbs 3:33)

The illocutionary act of the statement in Text 7 is informing. The presupposition is that God is generous and he sees everything including the houses of the just. The inference is that he doesn't bless ordinarily, the recipient must be just. The implicature is that he is awesome with power.

Text 8: "Children obey your parents in the lord" (Ephesians 6:1)

The quotation above has the following pragmatic breakdown: The illocutionary act is advising as the writer is passing across a didactic lesson to his reader/audience (i.e. children). The presupposition is that there are different kinds of parents i.e. parents in the lord and those who are not in the lord. The inference is that it is possible for children to be disobedient. The implicature is that the parents in the lord should be obeyed as they are good examples to follow.

Text 9: "If thou seek him, he will be found of thee" (1 Chronicles 28:9)

Text 9 has the following pragmatic exploration: The illocutionary act of the statement is advising. The presupposition is that God can be found if sought for by the reader/audience. The inference is that he is everywhere and it is possible to find him. The implicature is that if you don't seek him, you won't find him.

Text 10: "My son if sinners entice you, do not consent" (Proverbs 1:10)

The excerpt as shown has the following pragmatic interpretation: The illocutionary act of the statement is advising. The presupposition is that a father and a son (who are saintly) exist. The inference is that the father is indirectly instructing the son through a word of advice in our text. The implicature is that he loves his son and he doesn't want him to follow sinners.

Text 11: “In all thy way acknowledge him" (Proverbs 3:6)

Text 11 has the following pragmatic import: The illocutionary act of the statement is advising. The presupposition is that there is a God who should be acknowledged by the addressee. The inference is that "he" is superior to the addressee. The implicature is that God should be honoured everywhere.

\section{Text 12: "Other Books were given for your information. The Bible was given for our transformation"}

The quote above has the following pragmatic deduction: The illocutionary act is informing. The statement presupposes the existence of different books. Some books are for information, while the other book (i.e. the BIBLE) is for transformation. The inference is that unlike the other books, the Bible is unique and efficacious in life transformation. The implicature is that the Bible should be preferred to other books.

\section{Text 13: "The God who holds the universe is the God who is holding you"}

Text 13 has the following pragmatic exploration: The illocutionary undertone is informing. The presupposition is that there is a God, there are other gods, the former holds the universe and the addressee. The inference is that God is more powerful than any other god. The implicature is God is an overseer of all the earth.

Text 14: "If ye love me, keep my commandments" (John 14:15)

Text 14 has the following pragmatic deduction: The illocutionary act is advising. The presupposition is that both the addresser and the addressees are skeptical. The addresser(Jesus Christ, in this context) therefore gives the condition for loving him i.e. by keeping his commandment. The inference is that whoever violates his commandment does not love him. The implicature is that obedience is the hallmark of loving Jesus Christ.

Text 15: "Today if you will hear his voice, harden not your hearts" (Hebrews 4:7)

The quotation as shown has the following pragmatic analysis: The illocutionary act is advising. The presupposition is that there is a ruler and he is going to speak today. The inference is that he gives instruction. The implicature is that he doesn't speak to hardened hearts.

Text 16: "For I am the lord; I will speak and the word that I shall speak shall come to pass"(Ezekiel 12:25)

Text 16 has the following pragmatic elucidation: The illocutionary act is promising. The presupposition is that there is a lord who intends to speak an infallible word. The inference is that he is powerful. The implicature is that his words are unchanging because he does not lie.

Text 17: "I will go unto the King, which is not according to the law and if I perish, I perish"(Esther 4:16)

The passage as shown has the following pragmatic interpretation: The illocutionary act of the statement is promising based on the clause "I will." The story is about the boldness of Queen Esther in Esther 4:16 of the Holy Bible. The 
presupposition is that there is a king; there is a particular "difficult" law. The inference is that it is forbidden to break that law i.e. by going to the king at the odd hour. Violation of the law leads to death. But due to the exigency of the period, Esther promised Mordecai that she would go to the king. The implicature is that she is bold, she is willing to sacrifice to see the king.

\section{Statistical Analysis of the Data}

From the analysis so far, we may deduce that we have a preponderance of informing speech act which occurs eight times $(47.05 \%)$. This is followed by advising illocutionary act which appears seven times $(41.17 \%)$. Finally, promising speech act occurs, in our data, two times (11.76\%). Therefore, the data analysed above can be summarised with a table and a line chart as follows:

\section{A table representing the frequency and percentage of illocutionary acts}

\begin{tabular}{lll}
\hline Illocutionary Act & Frequency & Percentage \\
\hline Informing & 8 & 47.06 \\
Advising & 7 & 41.18 \\
Promising & 2 & 11.76 \\
Total & 17 & 100 \\
\hline
\end{tabular}

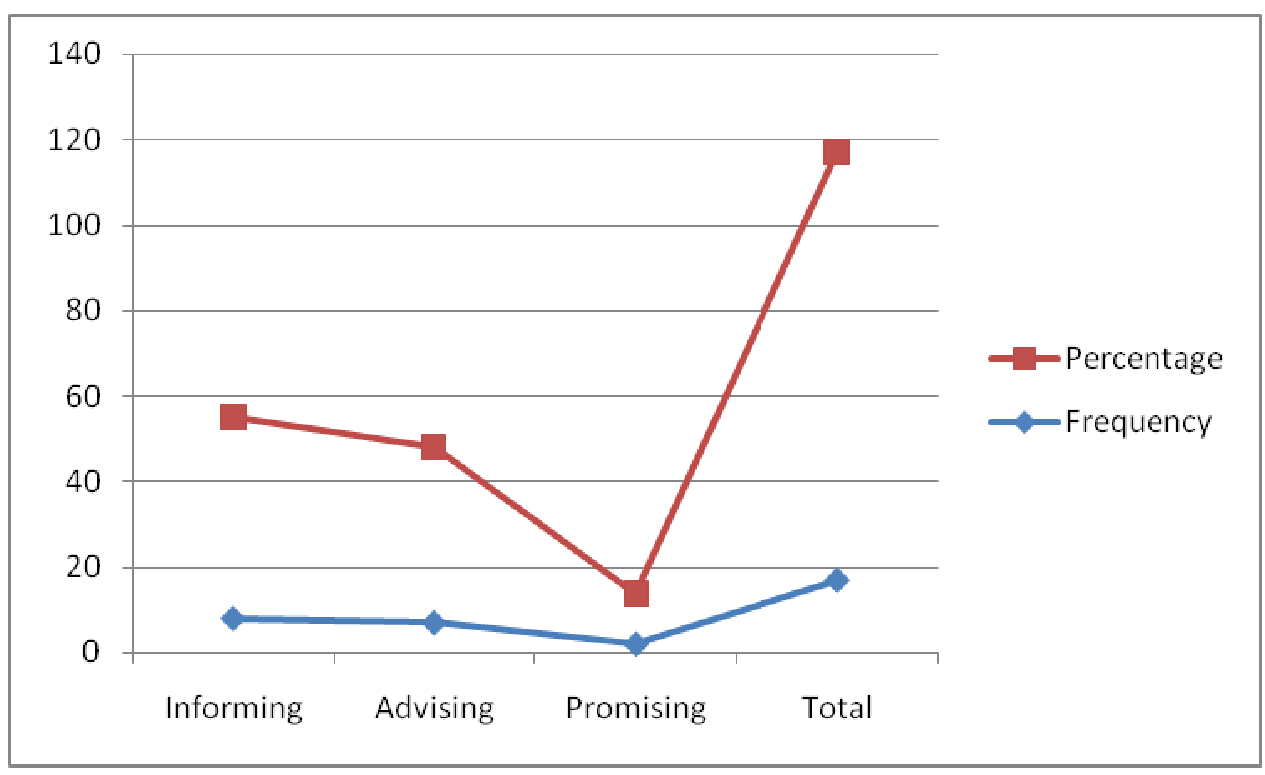

A Line Chart Illustrating Statistics of Illocutionary Acts

With the uniqueness of the informing and advising illocutionary acts which have $47.06 \%$ and $41.18 \%$ respectively, as demonstrated in the table and line chart above, we may infer that the billboards (in RCCG) are serving as instruments of information and advice among others.

\section{Implication}

So far in this study, we may deduce that the texts analysed are not just theologically designed. Rather, they are pragmatically encoded in order to reveal their textuality in the contexts of their usage(s). The study has demonstrated that the billboards are inundated with various meaning-making strategies which enhance their multifarious interpretations through the application of the speech act theory. The study thus affirms the submission of Oyeleye (2005, p.5) that meanings are constantly being reshaped through inevitable interaction in the minute aspect of the general society (taking RCCG as a minute aspect of the larger Nigerian society).

\section{Conclusion}

We may therefore conclude that thetexts studied, as displayed on the billboards in themain auditorium of the Redeemed Christian Church of God, Redemption Camp (Arena) are pragmatically important because they serve as 
weapons of gospel propagation for the global community and instruments of social interaction (advising, informing, promising) for the worshippers.

\section{References}

Adegbite, W. (1997).Pragmatics: Some Basic Principles and Procedures. In Lawal, A. (ed.) Stylistics in Theory and Practice. Ilorin: Paragon Books. Pp 60-79.

Adeyanju, D. (2008). Season's greetings from a cleric: A stylo-semantic analysis of Pastor Adeboye'snew year compliments.In Papers in English and Linguistic (PEL), Vol. 9, 2008, ISSN: 118-5902. Ile-Ife: Linguistic Association. Pp 85-94.

Ajibola, K. A. (2008).A linguistic stylistic analysis of some selected billboardadvertisements in Nigeria. B.A. Thesis, Unpublished. Redeemers' University, Mowe, Ogun State

Anko, P. (2010). Between explicatures and implicatures: Deconstructing the pragmatic interface in advertisements. In Okoro O. (ed.) Nigerian English in sociolinguistics'perspectives: Linguitics and literary paradigms. Nigeria: Pumark Nigeria Limited.

Austin, J.L. (1962). How to do things with words. Oxford: Oxford University Press.

Bankola, P.O. (2001). Beauty from ashes: A photo book on the holy ghost festival 2000. Lagos: El-Shalom Publishers.

Bloomer, A., Griffiths, P., \&Merrison, A. J. (2005).Language in use: A coursebook. New York: Routledge.

Grice, H.P. (1975).“Logic and Conversation”. In P. Cole \& J.L. Morgan (eds) Syntax and semantics 3:Speech Acts. New York: Academy Press.

http://proshareng.com/news/3349. accessed March 13, 2015

King James version of Theholy bible. England: Cambridge University Press.

Lasisi, O. (2008). A linguistic study of English usage in selected print media advertisements in Nigeria. B. A. Thesis, Unpublished. Redeemers' University, Mowe, Ogun State.

Lawal, R. A., Ajayi, B. \&Raji W. (1997).A pragmatic study of selected pairs of Yoruba proverbs, Journal of Pragmatics, 27, pp 635-652.http://dx.doi.org/10.1016/S0378-2166(96)00056-2

Lawal A. (2000).Pragmatics in Stylistics: “A speech-act analysis of Soyinka's Telephone conversation” In Babatunde A. O. (eds.) Studies in English language. Ibadan: Enicrowfit Publishers. Pp 150-172.

Levinson, S.C. (1983, 2005). Pragmatics. United Kingdom: Cambridge University Press.

Ogunsiji, A. (2002). “A speech act analysis of Soyinka's Etikerevowetin?” In Babatunde S. T. \& Adeyanju, D. S. (eds.) Language, Meaning and Society. Ilorin: Haytee Press \& Publishing Co. Nig. Ltd. Pp 209-223.

Oyeleye, L. (2005).“The new linguistic order: A critical examination of the impact of globalisation on the English language in Nigeria" In Olateju, M. \&Oyeleye, L. eds. Perspectives on language and literature.Ile-Ife: ObafemiAwolowoUniversity Press.

Osisanwo, W. (2003).Introduction to discourse analysis and pragmatics. Lagos: Femolus-Fetop Publishers.

Yule, G. (1985). The study of language.Cambridge University Press. 


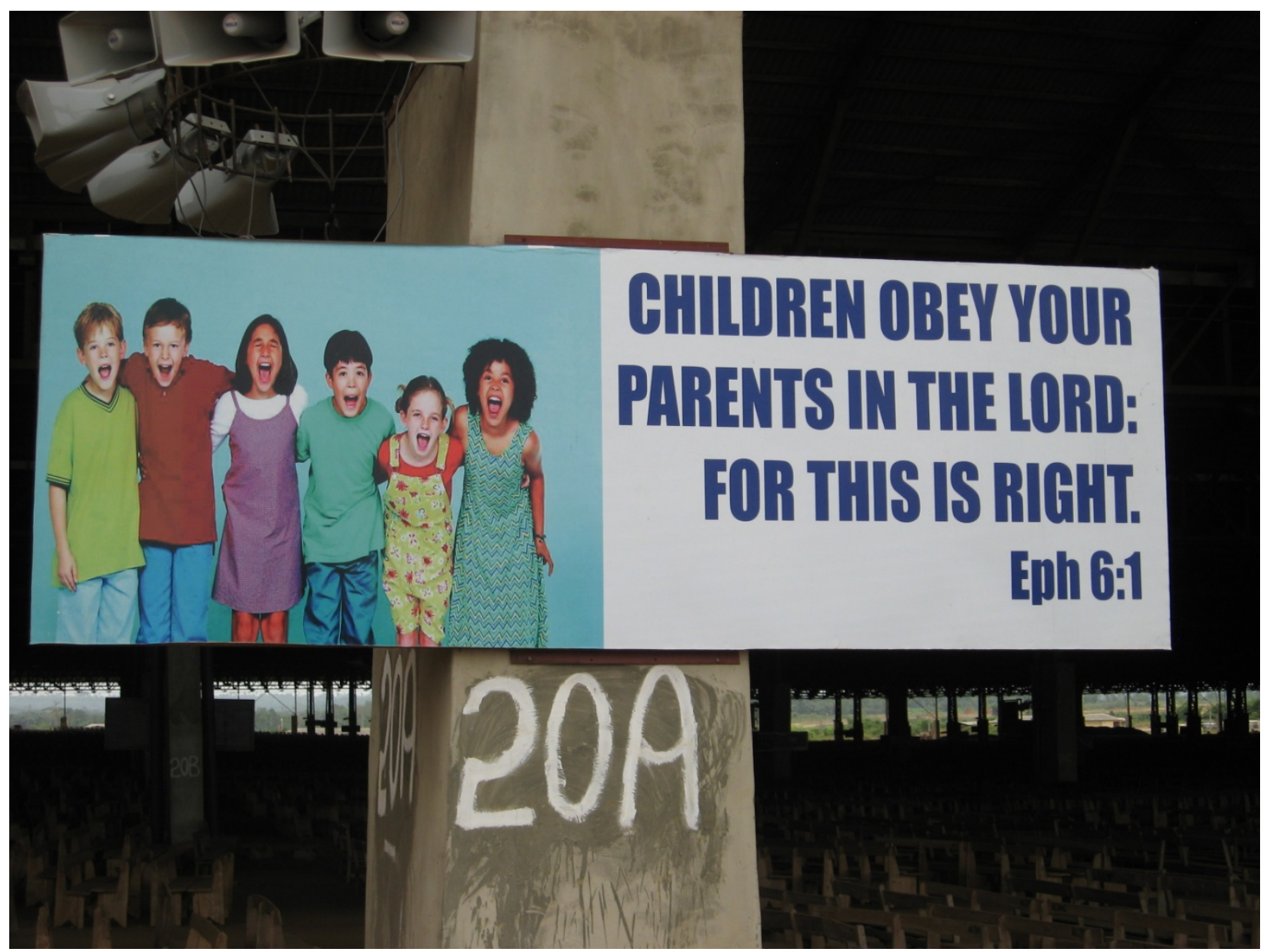

